NBER WORKING PAPER SERIES

PROSPECTS FOR LIBERALIZING

THE INTERNATIONAL TRADING SYSTEM

Anne 0. Krueger

Working Paper No. 2409

NATIONAL BUREAU OF ECONOMIC RESEARCH

1050 Massachusetts Avenue

Cambridge, MA 02138

October 1987

Paper prepared for International Economic Association Conference on "Survival and Growth in a Polycentric World Economy," Basel, Switzerland, 0ctober 14-17, 1987. The research reported here is part of the NBER's research program in International Studies. Any opinions expressed are those of the author and not those of the National Bureau of Economic Research. 
NBER Working Paper \#2409

October 1987

\section{Prospects for Liberalizing the International Trading System}

\section{ABSTRACT}

\footnotetext{
This paper enalyzes the equiliorium gegree of protection as the outcome ot the interaction of demands for protection and the demand for a Iiberal international trading order. It then assesses the current balance. on one hand, the nature of technical progress, the institution of the Uruguay Round the mounting costs of agricultural protection and the increasingly high asts of protection as the world economy integrates all conduce towaro a more liberal trading order. Demands for protection will intensify to the extent that growth decelerates, that trade negotiators tail to find mechanism to deal with nontariff barriers, and that the United states fails to assume this leadership role that was a arier taken.
}

Anne 0. Krueger 
Prospects for Liberalizing the International Trading System

The first half of the 1980 s was perhaps the most turbulent period for the international economy since the second world war. The second oil price increase in 1979-80 and the disinflationary response of most OECD governments led to a series of major economic difficulties. Worldwide recession resulted, and with it came a number of highly-publicized economic ills. These included the "debt crisis" of some developing countries, the drop in primary commodity prices, ultimately including oil, and the first drop (in 1982) in the value and volume of world trade in any year since the end of the Second World War. For the United States, some of the difficulty was at first hidden as expansionary fiscal policy offset tight monetary policy. However, as most economists had forecast, that imbalance gave rise to a series of events - including strong appreciation of the dollar, a sharp rise in real interest rates in the United States and abroad, and large swings in current account balances among the developed countries - which led to further dislocations both in the United States and in other major trading nations.

In these circumstances, it was small wonder that protectionist pressures grew strongly in many countries. Indeed, as I shall argue later, the real surprise should be that protectionism did not increase even more than it in fact did!

Now that the worst of the recession is several years behind us and moderate growth has resumed, it can be argued that the world economy is at a crossroads: either the protectionist pressures and measures of recent years will continue to mount, or there must be a fundamental reversal of those trends. Given the importance of that choice in affecting the future economic growth and levels of well-being of all nations, of conference on Survival and Growth in a Polycentric world Economy is certainly an appropriate place to 
assess the extent to which protectionism has increased, and to evaluate the prospects for future liberalization of the international economy.

As Adam Smith long ago pointed out, protectionist pressures are always with us. That has been true throughout the period since the second World War. At any point in time, the degree of liberalization of the trade and payments regime of any country, and also of the world at large, can be viewed as an "equilibrium" between the forces and demands for protection, on one hand, and those for a liberal international trading order, on the other.

Analysis of the prospects for a liberal international order must therefore start by identifying the factors tending to increase protectionism and those working toward free trade. That is the major thrust of this paper.

A natural starting point, in section 1 , is a brief review of the factors that led to the liberalization and growth of the international economy that was the hallmark of the 1945-1973 period. A second section containe an analysis of the changes in pressures, and the resulting shifts in trade policy and international economic relations in the period 1973 to 1986 from a macroeconomic perspective. The third section then focuses on some institutional issues that have arisen as a result of trade and growth in the international economy. Their resolution may prove the key to resumption of a trend toward liberalization. A final section provides an assessment of those factors in the international economy that can be expected to be conducive to continued liberalization of the system and those that seem likely to give rise to further pressures for protectionism.

1. The Golden Years of Trade Liberalization: 1945 to 1973.

There is little doubt that, several hundred years hence, economic historians will mark the third quarter of the twentieth century as being phenomenal in two interrelated regards: 1). the period witnessed sustained 
growth of the international economy at a rate far in excess of any rate earlier experienced in any part of the globe for a comparable time period; and 2) the long and sustained boom was accommanied (and in part led) by a tremendous liberalization in the economic relations among the developed countries.

It is now frequently forgotten that contemporary observers in the late $1950 s$ and early 1960 s attributed the rapid growth of the first postwar years to recovery, and regarded it as a transitory phenomenon. Instead, however, if anything economic growth accelerated, and with it the international economy became increasingly integrated. The late 1940 s witnessed the formation of the European Payments Union, as Europe began to move away from strictly bilateral clearing arrangements. During the early 1950s, convertibility for ourrent account transactions rose dramatically and European and Japanese exports began to grow rapidly. By the late 1950s, the first round of multilateral negotiations for tariff reductions took place, and currencies were becoming increasingly convertible. It is now often forgotten that as late as 1958 there were only four countries that had declared convertibilty under Article VIII.

Further trade and payments liberalization accompanied growth throughout the 1960 s and into the early 1970s. For present purposes, the important question is to identify those factors that contributed to the impetus to liberalization. It must, of course, be recognized that the process, once started, had a built-in momentum, as the rapid economic growth, resulting in part from liberalization itself, made further liberalization possible. Not only did growth make further liberalization easier, but in addition, some liberalization was a natural result of increasing foreign exchange earnings which permitted the authorities to remove remaining controls on current account transactions.

But a number of other pressures toward liberalization also facilitated the process. The Treaty of Rome and the success of the Common Market in its early 
phases resulted in de facto liberalization of trade. 1

Some of it was the result of the continued trend toward lower real costs of transport and communications - itself a major force for increasing the integration of the international economy. In addition to all of these phenomena, there was also the growth - gradual at the beginning but accelerating in the 1960 s -of the private international capital market, especially between North America and Europe which was not only important in its own right but also served as a further liberalizing factor in trade relations.

For understanding the momentum toward liberalization, it is also important to recognize the role of the United States. At least until the 1970 , there was a reasonably solid consensus that an open multilateral trading system was in American political and economic self-interest. Partly because foreign policy interests were regarded by some as being at least as important as economic interests, the United States could assume something of a leadership role in the international economy which was important in assuring the continued trend: American support for the European Payments Union, the Common Market, and the successive round of multilateral tariff negotiations under GATT at least facilitated these trade-creating activities and may have been a necessary condition for them.

If one were to identify forces for liberalization in the $1950 \mathrm{~s}$ and 1960 s, then, they would include: 1) the political momentum of growth which in part reduced political pressures against liberalization (which permitted the reduc-

1. This is one important illustration of the proposition that institutions do significantly matter. See, for example Jean-Francois Hennart, "The Political Economy of Comparative Growth Rates: the Case of France", in Dennis C. Mueller, ed., The Political Economy of Growth, 1983, Yale University Press. Hennart argues that the common Market resulted in "the neutralization of growthretarding common-interest organizations:... first, French sovereignty over some important economic matters has been reduced. Second, the power of French organized interests has been adversely affected by the internationalization of the French economy." (P. 189). 
tion of trade restrictions within the common Market to accelerate), 2) the strong commitment of the United States to an open international trading system and the willingness of that country to take a leadership role in the GATT and in successive rounds of trade negotiations (notwithstanding the American Congress' refusal to ratify the International Trade Organization), 3) the costs (which had been an almost constant source of increasing integration of the international economy since the early 1800s); and 4) rapid economic growth itself, which both resulted from and fed the liberalization process among the developed countries.

There were, however, some offsetting pressures toward increased protectionism. Chief among these was the tendency among almost all developing countries to adopt highly restrictionist trade and payments regimes, and to attempt to insulate their domestic economies from the international market; by the 1960 s, this was strongly reflected in the declining shares of exports and imports in most developing countries' national incomes and developing countries' demands for a Generalized System of Preferences (GSP) and departures from the multilateral system. However, there were other protectionist pressures. The first nontariff measures restricting trade in textiles were taken in 1955, with a prearsor of the current Multifiber Arrangement (MFA) . 2 In similar vein, the United States had opposed the inclusion of trade in agricultural products within the GATT and the EC was developing policies which were, at first, only mildly restrictionist but which would, later on, become highly so as European agriculture responded to these measures.

The extent of protectionist pressures during the 1950 s and 1960 , is of ten forgotten. Writing in the mid-1970s, Charles R. Frank, Jr. could talk about

2. For a history and analysis of the MFA, see Donald $B$. Keesing and Martin Wolf, Textile Quotas Against Developing Countries, Trade Policy Research Center, London, 1980, Chapters 2 and 3. 
the "crisis of protectionism" of the late $1960 \mathrm{~s} .3$ The most restrictionist piece of legislation to gain serious support in the U.S. Congress was the BurkeHartke Bill in 1969, which was defeated in the House of Representatives by one vote. Thus, even in the heyday of trade liberalization, it was not true that all pressures worked toward liberalization, nor that there was no opposition to an open multilateral trading system.

Table 1 provides some data on the growth of world trade and world GNP. As can be seen world real GNP is estimated to have increased 2.6 times in the two decades following 1950, implying an average annual rate of growth of 4.96 percent and a rate of growth of per capita income of about 3 percent. This contrasts with economic historians' estimates that the most rapidly growing countries in the nineteenth century experienced growth rates of about 1.5 percent per capita, and of course, most parts of the world experienced little or no growth during that century.4

During the same two decades from 1950 to 1970 , the volume of world trade expanded even more rapidly, increasing 4.8 times, for an average annual growth rate of 8.1 percent. As alreacy mentioned, most of that growth of trade was concentrated in the OECD countries, as the shares of most developing countries in world trade were falling.

Table 2 provides summary statistics showing the relationship of trade growth to world GNP growth. The first column provides estimates of the elasticity of world trade in manufactures with respect to real growth of world GNP. From 1950 to 1955, for example, world trade in manufactures grew 1.2 percent for every percentage point growth in world trade. The overall volume of

3. Charles R. Frank, Jr., Foreign Trade and Domestic Aid, Brookings Institution, 1977.

4. See A. G. Kenwood and A. L. Loughheed, The Growth of the International Economy 1820-1980, Allen and Unwin, London, 1983, Ch.1. 
trade, manufactures and primary commodities, grew 1.14 percent for every percentage point of real growth. Those elasticities INCREASED throughout the 1950 s and 1960s, reaching 1.32 for manufactures and 1.19 for total trade in the 1965-70 period. Because an elasticity greater than 1 imolies a rising share of trade in GNP, the rising elasticities are even more remarkable: ultimately they must decline and approach I (as all goods become traded, if not before).

As the data in Tables 1 and 2 bring out clearly, by the early 1970s, the international economy was vastly more open and integrated than it had been twenty years earlier. It could fairly be said that successive rounds of liberalization of trade had resulted in a situation in which tariffs were no longer a significant barrier to trade in manufactures among the OECD countries. At the end of the Kennedy Round, it was estimated that tariffs on dutiable nonagricultural products averaged 9.9 percent in the United States, 8.6 percent in the European Community, 10.8 percent in the United Kingdom and 10.7 percent in Japan.5. Further cuts, negotiated during the Tokyo Round, and scheduled to take effect during the 1980s, had left tariffs which were bound at extremely low levels among the industrial countries.

As already mentioned, the European community was not, in its early years, a trade-diverting organization. Increases in agricultural productivity in the early post-war years were probably economically efficient and thus it is likely that agricultural protectionism did not significantly worsen at least until the late 1960 s and possibly until the entry of the U.K. into the common Market.6 Trade in manufactures expanded rapidly both within Europe and between

5. Robert E. Baldwin, Nontariff Distortions of International Trade, Brookings Institution, 1970 , P. 1 .

6. For an elaboration of this argument, see Anne 0. Krueger, "Protectionism, Exchange Rate Distortions, and Agricultural Trading Patterns", American Journal of Agricultural Economics, December 1983. 
Europe and the rest of the world in response to reduced tariff barriers.

\section{Conflicting Trends: 1973 to 1986}

The inflationary pressures and comodity boom of the early 1970 s culminated in the three-fold increase in the price of oil in the fall of 1973. Until that happened, world trade had expanded rapidly. Although the major trading nations had abandoned the Bretton woods system of fixed exchange rates by the spring of 1973, that abandorment had come about because of the intolerable pressures placed on countries attempting to support their currencies in the face of large international capital flows - themselves the result of the integration of the private international capital market.

With the oil price increase, however,? a new set of strains enveloped the world economy. Between 1973 and 1980, for the most part, these tensions were met primarily through accelerated inflation. Protectionist rhetoric grew sharply, and world economic growth decelerated. Nonetheless, in an inflationary environment, deceleration was not pronounced, as can be seen in Table 1: between 1960 and 1970, world real GNP had increased by 69 percent; between 1970 and 1980 it rose by 47 percent. Likewise, the growth of world trade continued to outpace the growth of world GNP, rising by 63 percent over the decade. Although slightly less buoyant than in the 1960s, the elasticity of manufactured trade with respect to output remained well above one, while the elasticity with respect to total world trade fell to 1.04 and 1.06 , largely reflecting a reduced volume of trade in oil.

As in the 1950 s and 1960s, there were some pressures for increased protection and some for more liberal trade. Noteworthy among those factors

7. It can plausibly be argued that had the exchange rate system not changed prior to the oil price increase, the magnitude of the effects would have been far greater and more serious than it in fact was. 
tending to integrate the international economy were the shift in policies of a significant number of developing countries.8 Likewise, concern over inflation rates was a significant consideration for many countries in their decisions to maintain open trade policies. Lower real costs of transport and communication continued to serve as an integrating force. And, of course, the Tokyo Round of trade negotiations insured further cuts in already-low tariff rates among the industrial countries.

Offsetting these factors, however, some protectionist pressures intensified. There were several renewals of the Multifiber Arrangenent, each apparently on more restrictive terms than the last. A number of other "Voluntary Export Restraints", and an EC agricultural policy which was increasingly protectionist in effect also reflected an increase in protectionist pressures. In addition, pressures on iron and steel, shipbuilding, and other traditional industries intensified, and, in the context of labor market rigidities and high unemployment, these phenomena also increased protectionist pressures.

Underlying these intensified pressures were several identifiable factors: 1) higher unemployment rates in Europe and North America following the oil price increase clearly increased the calls for protection; 2) associated with higher unemployment was slower growth of real GNP, which also contributed; and 3) the emergence of some developing countries as significant exporters of labor-intensive manufacturers intensified pressures for adjustments in domestic industries which were naturally resisted.

These three sources of pressure were clearly interrelated: slower growth was in part the cause of high unemployment, and, to the extent that high unemployment rates were structural, they contributed to slower growth.

8. See Anne 0. Krueger, Foreign Trade Regimes and Economic Development: Liberalization Attempts and Consequences, Ballinger Press, 1978, Pp. 37-40 for a discussion of this trend. See also world Bank, World Development Report 1987. 
Likewise, the penetration of developed countries' markets for manufactures would have resulted in less discomfort in an enviroment of more rapid growth and more rapidly expanding employment opportunities in the expanding activities of the industrial countries.

However, it was difficult to provide meaningful numbers with which to document the rise in protectionism. Indeed, in 1982, Helen Hughes and I wrote a paper in which we attempted to show that the data did not bear out the thenprevalent view that protectionism had inoreased sharply, at least toward the developing countries that were widely believed to be the target of most protectionist measures. We concluded that:

"....the overwhelming impression is that despite all the public discussion of protection and the political pressures for it, the effects on imports of manufactures from developing countries of protectionist measures were relatively small. The rate of increase of LDC market shares was sufficiently great that it is difficult to imagine that rates would have been significantly higher in the absence of any protectionist measures."9

In the aggregate these remarks are also borne out by the data in Tables 1 and 2. The elasticity of trade in manufactures with respect to world GNP growth was 1.14, somewhat lower than it had earlier been, but it was recognized that earlier rates of growth of trade were probably unsustainable. Moreover, insofar as world real GNP had grown more slowly, there was fur ther reason to accept the recorded figure as being well within the range that was consistent with maintenance of the open international trading system.10

9. Helen Hughes and Anne O. Krueger, "Effects of Protection in Developed Countries on Developing Countries' Exports of Manufactures", in Robert $E$. Baldwin and Anne 0. Krueger, eds., The Structure and Evolution of Recent Trade Policy, University of Chicago Press, Chicago, 1984.

10. There is also a question as to whether the more rapid growth of services trade might not tend to lower the recorded trade-GNP elasticities. For present purposes, however, that question is not central to the argument and is therefore ignored. 
Overall, the diagnosis on the period 1973-1980 must be that protectionist pressures increased enough during the late 1970 s to reduce the momentum toward a more liberalized international economy but that protectionist forces had not grown enough to lead on balance to a more restrictive international trading system. While protectionist pressures had intensified enough to slow down the thrust of liberalization, they were not strong enough in that period, at least according to observable data, to outweigh the continuing momentum of liberalization.

Then came the events of the early 1980s: the antiinflationary response to the oil price increase by the OECD countries, the worldwide recession of the early 1980 s and the inability of many developing countries to continue servicing their debts in those circumstances, the appreciation in real terms of the U.S. dollar and the large capital inflows into the U.S. in response to high real interest rates associated with expansionary fiscal and tight monetary policy.

It cannot be doubted that protectionist pressures intensified. The higher unemployment associated with worldwide recession was one key factor. As always, the slowdown in growth itself contributed directly to increased protectionist pressures. Likewise, in developing countries, the trend toward more open trade and payments regimes of the 1970 s was halted and in many cases significantly reversed as debt-servicing difficulties led to quantitative restrictions on imports and the reintroduction of high barriers to imports. And, as heavily indebted developing countries reduced their imports from the developed countries while simultaneously attempting to increase their exports, that put further pressure on significant sectors of economic activity in the developed countries. And, perhaps most significant of all, the real appreciation of the dollar put tremendous pressure on American exporting and importcompeting interests, and led to wholesale reduction of support for an open 
trading system in that important country.

Meanwhile, some protectionist tendencies, earlier at work, intensifed. Chief among these was the impact of the EC agricultural policies; earlier, the EC's protectionism had resulted in reduced imports of agricultural commodities from the rest of the world; by the 1980s, those policies had resulted in such large increases in output that the EC became an exporter. For many countries, including the United States, this put considerable pressure on agricultural exporting interests, and eroded yet another base of support for free trade.

Even the early 1980 s was not entirely bleak, however. A few significant developments did tend to result in pressures for increased trade liberalization. First and probably most important, the technology of the "third industrial revolution" in information and communications system greatly increased the gains to be realized from an open international trading system. Not only were time and distance costs of communication and transmission of information reduced, but the new technology permitted the geographic separation of engineering and other highly skilled activities from physical production to a much greater degree than was earlier possible. Simultaneously, the new technology increased the premium to be placed on large production runs of highly specialized parts and components of complex equipment: a situation in which the gains from trade are enormously greater, and in which firms which can operate in more than one geographic region will have an enormous competitive edge over firms constrained by protection to operate only in their home markets.

secondly, a number of countries' policy-makers reversed past protectionist policies, either because the need for greater efficiency was recognized or because the harsh realities of the world of the 1980 dictated such a reversal. Notable and early starters among them were such diverse countries as Turkey and New Zealand. While those early starts were to a considerable extent offset 
by increases in protectionism elsewhere, they maintained their momentum toward more liberalized and open economies, while other countries began moving in the same direction by 1984 and 1985.

As the data in Tables 1 and 2 indicate, the growth of world GNP slowed down markedly in the early 1980s. Despite that, the elasticity of world trade with respect to world GNP remained 1.03, while that for manufactured exports was 1.12. Although those numbers are not as impressive as the 1.32 and 1.19 figures for 1965-70, they nonetheless are not consistent with the view that the world had turned entirely away from the earlier open international economy.

Some further evidence supporting this conclusion is contained in Table 3. There, data used by Hughes and Krueger is updated. Focussing on developing countries' exports (which have, after all, been a major focal point of protectionist pressures), the numbers clearly show that the developing countries' shares of world exports of manufactures rose from 8.9 percent in 1980 to 11.9 percent in 1985. Except for the 1984-85 drop (and it might be argued that 1984 was the abnormal year), there is little in the data to show any significant retardation of the trend toward larger shares. While the increase might have been larger in the absence of protectionist measures, an increase of about one-third in share in a period of five years is hardly consistent with highly restrictionist trade practices on the part of the importing countries. Given theslow economic growth in the international economy and the turbulence of the early 1980s, what is perhaps most remarkable is that developing countries' share of world trade continued to grow, and that there continued to be an increasing fraction of world output that entered into international trade.

It is evident, therefore, that the world economy is at a crossroads: either the pressures for liberalization will increase, or the world will move away from the open multilateral trading system that served it so well over the 
1945-1980 period. Before assessing the pressures working toward and against liberalization, however, a number of institutionalissues, that may have an important bearing on the outcome, require examination.

\section{Institutional Arrangements and Prospects for Liberalization}

Thus far, discussion has taken place in terms of conflicting pressures for trade liberalization and for protection. However, it was recognized that institutions matter, and that institutional arrangements strengthened some pressures. The GATT itself was such an institution as the existence of multilateral trade negotiations, and the practice of binding negotiated tariffs, was conducive to greater reductions in tariffs than might have been politically feasible unilaterally.

A question arises as to the efficacy of the present institutional structure in restraining or intensifying protectionist pressures. On one hand, tariffs are no longer the principal instrument of restrictive trade policy. Moreover, a number of countries have emerged as important international traders and it can be questioned whether the techniques of bilateral tariff negotiations among a limited number of large trading blocks, the institution which worked so well for tariff reductions, is appropriate in today's world.

If one examines the list of issues that trade representatives have raised for the Uruguay Round of trade negotiations, many of them focus on areas where the current international institutional arrangements seem less adequate than they were for tariff negotiations.

Clearly the concerns which have led to the emergence of NTBs, agricultural distortions, and protectionist measures against the NICs are to some degree the outcome of the competing pulls of pressures for protection and for an open trading system discussed in sections 1 and 2. Economic growth and technical change have both served to increase the relative importance of trade in 
services, another issue over which some degree of trade friction has arisen.

In all these cases, however, institutions matter. The institution of the EC, when it was founded, was itself a force for liberalization. Likewise, the successsive rounds of trade negotiations were an institution which restrained countries from unilateral increases in tariff protection and simultaneously made is relatively easier to resist protectionist pressures in particular sectors. If institutions can be adapted to address the new issues reasonably satisfactorily, protectionist pressures will have less force relative to those for an open international economic order. In this section, the main institutional issues associated with the major trouble areas are addressed.

\subsection{Nontariff Barriers}

The success of the GATT has been that tariff barriers to trade, at least among most of the industrial countries, have been virtually eliminated. It might be argued that many of the nontariff barriers (NTBS) to trade in manufactures have been put in place becausee tariffs were bound and countries could not resort to their use under the GATT. On that view, elimination of tariffs has simply induced countries to substitute less transparent for more transparent means of protection.

However, it is at least equally plausible that, mercantilist though they are in spirit, multilateral negotiations for reducing trade barriers are an effective institutionreducing the force of protectionist pressures. The institutional arrangement of multilateral negotiations may in fact lead to a recognition that protection of some activities is disprotection of others, and lead to improved societal decision making as it forces recognition that protecting some activities necessarily foregoes exports in other lines of economic activity.

To the extent that this latter view has validity, finding mechanisms to 
permit multilateral negotiations to reduce nontariff barriers to trade assumes urgency. For, to date, NTBs have been negotiated on a sector-by-sector basis. For example, the MFA is negotiated separately from NTBs in steel, which are again treated separately from agricultural NTBs. Thus far, countries have not found means of "putting NTBs on the table" in a manner which would permit, for example, reduction or removal of the MFA by the developed countries, reduction in agrioultural NTBs by Europe and Japan, reduction in quantitative restrictions on imports of capital goods by developing countries, and liberalization of the NICs' markets for labor-intensive goods. Clearly, 'institutional arrangements which lead to sector-by-sector negotiations are more likely to be protectionist than arrangements which result in negotiations among Ministers responsible for an overview of the economy. And, to date, there seems little basis to believe that "Codes" are an entirely satisfactory answer.

There are precedents, such as the phased liberalization of quantitative restrictions under the European Payments Union and Japanese removal of QRs, which could be used to devise across-the-board quantification of NTBS with a view to negotiations as to the rate at which they would be eliminated. To date, however, there has been little effort aimed at developing such a framework. Failure to do so will surely strengthen the ability of protectionists in the affected sectors to increase barriers to trade.

\subsection{Barriers to Trade in Agriculture}

If one were to attempt to identify trends in the world economy since 1970, one important one would surely be the impact of increasingly restrictive agricultural policies by Japan, the EC, other European countries, and to a lesser extent the United States.

It can, of course, be argued that there are pressures for liberalization within those countries that are protecting their agriculture. Chief among 
these is that the budgetary costs of continued protection are rising. Secondarily, there are some indications that consumer awareness of the costs of protection in agriculture is increasing.11 Possibly more important, however, is the fact that there are a significant number of countries, both developed and developing, that are net exporters of agricultural commodities. These countries' goverments recognize the damage that agricultural protection is inflicting upon their own producers.

Because of this, several institutional questions arise. A first is why agricultural issues are outside the sphere of GATT. Their omission has certainly rendered agricultural protection easier. A second question is whether institutional means can be devised so that coalitions of countries can represent their interests jointly. That issue has ramifications far beyond agriculture, and is the subject of sect. 3.3

\subsection{Bilateral Bargaining}

The GATT represented a highly satisfactory forum for trade negotiations among the large trading nations: the U.S., the EC, EFTA, and Japan. However, now that the large trading nations themselves are concerned with the trade policies and practices of NICS and some of the larger developing countries, it is questionable whether the "bilateral reciprocity" techniques that characterized the earlier rounds of trade negotiations will be quite as effective in inducing the multiple-party, multiple-commodity negotiations that current issues seem to warrant.

The absence of workable techniques for establishment of coalitions of exporters renders their effective representation difficult. Although the so-

11. See Kym Anderson and Yojiro Hayami, The Political Economy of Agricultural Protection, Allen and Unwin, Australia, 1986, for an analysis of the factors leading to protection, especially in Japan. 
called "Cairnes group" of agricultural exporters has certainly made a start in that direction, the institutional problems of their common representation (which are probably mirrored by exporters of textiles, clothing and footwear) are far from resolved. Even among the Cairnes Group, there are identifiably separate interests between exporters of temperate and of tropical commodities, for example. There are, however, also common interests among all agricultural exporters. Existing arrangements seem conducive to emphasizing the differences in interest, and to discourage coalitions of a kind which would provide incentives for acting in concert for common interests.

If institutional mechanisms could be devised for simultaneous bargaining between, say, agricultural exporters and importers, textile and clothing exporters and importers, exporters and importers of electrical and electronic equipment, and exporters and importers of mechanical machinery and equipment, it would certainly increase the likelihood that attractive packages of trade barrier reductions could be devised. Nonetheless, as even this simple example suggests, finding a mechanism to accomplish this is fraught with difficulty.

The "Cairnes Group" represented the first attempt to devise one such coalition. The problems associated with devising arrangements conducive to coalitional representation seem formidable. Their absence, however, reduces the strength of the pressures for liberalization in a polycentric world.

\subsection{Trade in services}

In the past, the majority of international trade consisted of the exchange of physical goods among countries. These goods might have been produced with services as inputs, but the technology of international trade was largely that of transporting commodities from one country to another. That technology, in turn, led to the use of tariffs and other measures which could be administered at the border, when the good physically entered the country. 
Services, and especially services of a type used as an input into production, have increased in importance as specialized finance, insurance, engineering skills, and other lines of activity have developed. The informatics revolution, currently in progress, will increase this tendency even further.

To a considerable extent, this trend in itself represents a presssure toward liberalization. It is far more difficult (and it may prove far more costly) to regulate international transmission of computer designs and financial data than it is to regulate shipments of coal and steel. However, there may be national concerns (such as a desire to have at least a specified fraction of television originating from national sources) which lead to some interventions, and these may not be border interventions.12 At the present time, there are few satisfactory institutional arrangements for dealing with these issues. As the informatics revolution proceeds, and as services grow in creasingly important, the development of such mechanisms may prove increasingly important as a factor in conducing toward an open international trading system.

\subsection{Role of the Developing Countries}

Many of the issues discussed above - NTBs (and especially the MFA), trade in agricultural commodities, and coalitional issues - are of immediate concern to the developing countries. They need not be repeated here. There are, however, two additional issues which deserve at least brief mention.

First, many developing countries have liberalized their trade and payments regimes in their own self-interest, of ten in conjunction with IMF and/or world Bank programs. At present, there appears to be no very satisfactory mechanism

12. See Richard Snape, "Trade in Services", World Bank Economic Review, Vol, 2,No. 1, July 1987, for a full analysis of the issues that arise in connection with service trade. 
by which they can "get credit" for prior liberalization during GATT negotiations.. Although developing countries could, in the course of GATT negotiations, bind their liberalized tariffs, a significant issue of credibility might arise because of the balance of payments provisions and infant industry exceptions to which they often resort. Mechanisms for recognizing liberalization on the part of developing countries as part of a the new Round could serve as an additional inducement to trade liberalization on their part, and would simultaneously represent a constructive move in bringing developing countries more into the GATT framework.

The second issue is somewhat less obviously institutional in nature, but nonetheless requries mention. That is, the developing countries have traditionally asked for, and received, special and differential treatment within the GATT. Thus, they have received preferential tariff treatment under the Generalized System of Preferences from most industrial countries, and have focussed much more on that aspect than on their stake in the multilateral system. If mechanisms could be devised which would more clearly reflect the importance of the multilateral system to the developing countries, that might serve as a useful force toward maintaining an open trading system. It could also be useful as a step in developing useful coalitional arrangements, and in bringing aid officials in developed countries to support trade liberalization more strongly within their own governments. 13

\section{The Crossroads}

As Sections 1 and 2 demonstrated, there are always pressures for protection and forces leading to a more open international economy. During the

13. For an analysis of some of the issues concerned with developing countries' use of the balance of payments provisions of the GATT, see 3 . J. Anjaria, "Balance of Payments and Related Issues in the Uruguay Round of Trade Negotiations", World Eank Economic Review, July 1987. 
period up to 1973, the tendency toward a more open international trading and payments system clearly was stronger than protectionist pressures, although they were by no means absent. From 1973 to 1980 , protectionist pressures increased enough in strength so that, for the international economy as a whole, there was something close to an impasse: protectionism may not have resulted in increased protection, but it did increase enough to dampen halt the trend toward an increasingly open world economy.

During the early 1980 , protectionist pressures clearly had the upper hand: worldwide recession and the high unemployment that accompanied it strengthened protectionist forces in the developed countries, while declining commodity prices and problems associated with heav indebtedness led many developing countries to reverse earlier efforts to liberalize their trade and payments regimes. The American support for a free trade position was significantly weakened by the strength of the dollar, which along with disinflation, put considerable pressure on a large number of economic activities.

The recession is over, and worldwide growth has resumed, albeit at rates slower than those of the 1950 s and 1960s. Agreement has been reached on a new round of trade negotiations, aimed at liberalizing the international economy and addressing, in particular, some of the issues disoussed in section 3 . It can plausibly be argued that the antiinflationary programs of most of the OECD countries have been successful in reducing inflation, and that many of the structural problems that afflicted some countries, especially in Europe, in the 1970 s and early 1980 s, appear to be approaching resolution.

On that reading, one could argue that if the pressures toward liberalization were once again on the ascendancy, worldwide growth would likely accelerate which, in turn, would be conducive to further liberalization. The "virtuous circle" of liberalization-growth-liberalization which characterized the 1950 s and 1960 s might reappear. 
However, one of the critical questions is whether forces for liberalization will increase in strength, or whether in fact protectionist pressures have not so strengthened as to imply that the open international trading system of the 1950 s and 1960 s is a thing of the past. Clearly, no one can forecast the outcome. All that can be done is to identify those elements in the international economy conducive to liberalization, and those resulting in increased protectionist pressures.

\subsection{Factors Conducive to Renewed Liberalization}

There are several factors conducive to renewed liberalization of the international economy. $\quad 8 y$ and large, they are underlying trends, and not the sorts of things that make day-to-day headlines, but their power should not be underestimated. Indeed, it can be argued that the failure of the world economy to turn even more protectionist in the early 1980 s can only be attributed to the strength of these forces, and that what is really surprising, in light of the severity of the recession and the rise in unemployment, is that the open international trading system survived as well as it did.

A first factor, already mentioned, is the nature of technological change arrently in progress. Both because economic growth is now taking place in activities with very low transport costs and because it is focussed on increasingly specialized activities where large production runs of highly specialized items call for large, international markets, technological change appears to be largely on the side of further liberalization of the international economy. 14

14. In this regard, it is interesting to note that the strength and intensity of opposition to the U. S. Administration's effort to prevent imports of Toshiba's products to the U.S. market. Not only have consumer groups protested, but a surprising number of large American corporations have publicly protested, claiming dependence on the importation of itens they can-not obtain elsewhere at reasonable cost. See New York Times, Sept. 17, 1987, P. 
A second factor, perhaps equally strong, is the powerful pull of the idea of an open international economy. Despite the numerous pressures for protection, most advocacy is couched in terms of "unfair practices of the other country", "national defense", or other reasons which broadly accept the notion of open international trade as the norm. The fact that the $1950 \mathrm{~s}$ and $1960 \mathrm{~s}$ were so prosperous and that trade liberalization was then ocourring supports and reinforces this ideology.

The third factor is the start of the Uruguay Round itself. Although the fact that the Round has started by no means assures its success, it does impose a certain discipline on the contracting Parties. Should sufficient agreement be reached for the Round to be deemed a success, that will further diminish protectionist pressures.

There is also some basis for optimism with regard to agricultural protectionism. In part, optimism must be based on the very high, and rising, costs of maintaining protection. Both because some of these costs are budgetary and rising, and because the authorities are confronted with the painful choice between passing on inoreasingly high costs to consumers and inourring evergreater budgetary costs, there is a basis on which to believe that agricultural protectionism must diminish of its own weight.

Fifth, there is the consideration that financial and trade linkages are now so important that a significant polarization of the world economy will prove highly unattractive to almost all governments. The most visible manifestation is linkage between developing countries' abilities to expand their exports and their ability to maintain their debt service. In itself, that represents a compelling reason why many industrial countries must contain protectionism. Other ties, represented by foreign direct investment, multinational firms, and established trading relations, should not be underestimated.

Sixth, a number of developing countries are starting, or continuing, to 
liberalize their trade and payments regimes unilaterally. In many instances, these decisions are the result of a painful recognition of the degree to which earlier, highly restrictionist, trade and payments regimes had been inimical to growth.

Finally, to the extent that economic growth is resuming in Europe, and that trade imbalances between Japan and the industrial countries are somehow remedied, pressures for protection should be diminished.

\subsection{Pressures for Protectionism}

Despite these factors tending toward a more open international economy, there are a number of factors tending in the opposite direction.

Perhaps chief among them is that the commitment to an open multilateral system has eroded, and that in itself reduces the discipline that earlier helped reinforce liberalization. An important part of that erosion has been the reduced support for an open international trading system in the United States. Although the strength of the American dollar in the early 1980 s contributed significantly to that reduction, the American ourrent account deficit, and the associated economic pressures, are likely to persist as long as the U. S. fiscal imbalance remains sizeable.

Many observers believe that the American fiscal difficulties will not be resolved without a period of slow growth or recession. If that view is correct, that would strengthen protectionist pressures both in the United States and in the rest of the world. The United States is important both because of her size and because of her traditional role, now largely abandoned, as a leader in the international economy. Should the United States experience economic difficulties, that would certainly tend to brake economic growth in the rest of the world, thereby strengthing protectionist forces there. Much therefore depends on the American ability to resolve the current fiscal- 
monetary imbalance without inourring high costs in terms of foregone output.

Thirdly, however, the absence of adequate institutional mechanisms that would permit simultaneous bargaining over a variety of NTBs, the development of meaningful coalitions, and the other issues discussed in section 3 clearly does not portend well for the prospect that trade liberalization will once again reach ascendency over protectionism. Whether it is this inadequacy or the strength of protectionist forces itself is difficult to evaluate, but certainly a great deal hinges on the prospects for a successful conclusion of the Uruguay Round. Just as success would almost certainly tip the balance toward resumption of liberalization of the international economy, failure would intensify protectionist trends. The absence of visible momentum in those negotiations is therefore a factor itself tending toward the strengthening of protectionism.

Fourthly, it is surely easier to forego the imposition of a tariff or quantitative restriction than it is to remove an existing one. Once in place, protectionist measures tend to induce the formation of political interest groups committed to their maintenance. To the extent that the early 1980 s witnessed the introduction and/or strengthening of protectionism, it will be more difficult to roll back those measures than it would have been to move forwrd in their absence.

Fifth, at present there is no visible leadership to push for liberalization. The role played by the United States in the 1950 s and 1960 s has not been assumed by any country or group of countries. While leadership alone cannot determine the direction of trade negotiations, the presence of a visible country or group of countries representing the systemic interests in the international economy was clearly important in the 1950 s and 1960 s. The absence of corresponding leadership in the mid-1980s will certainly weaken the effectiveness of those pressures tending toward liberalization. 


\subsection{The Balance}

Any attempt to assess the relative strength of the pressures toward liberalization and protectionism must necessarily involve a great deal of judgment and in any event be subject to an extremely wide margin of error. Certainly, there are conflicting pressures in both directions, and it is by no means clear what the outcome will be. Because both liberalization and protectionism tend to be somewhat self-reinforcing, the international economy is truly at a cross-roads.

Rather than attempt the impossible task of forecasting the outcome, it may be preferable to conclude by examining the likely shape of an increasingly protectionist world. In such a world, it is probable that sizeable trading blocks would emerge: the EC and EFTA would constitute one block, incorporating many of the LOME convention countries into their trading relations. Japan would surely lead another block, consisting arguably of some Southeast Asian nations, possibly of Australia and New Zealand, and possibly some Latin American countries. The United States would almost surely lead a trading group containing some Latin American countries and Canada, with possibly some others. Where the trading ties of the Middle East, the Indian subcontinent, and China would be is purely speculative.

Even attempting to imagine the economic and political ramifications of such a polarization is enough to lead to a conviction that such an outcome would be vastly inferior, from the viewpoint of each of these blocks, to an open international trading system. Those persuaded of this can shift the likelihood of such an outcome if the institutional issues, discussed in sect. 3 , can be satisfactorily addressed. 
Table 1. Growth of World Exports and Real GDP, 1950-1985

Volume of Exports $1970=100$
Agriculture Manufactures Total (billions of dollars) Fieal GNP

$\begin{array}{lrrrrr}1950 & 42 & 16 & 21 & 61 & 38 \\ 1955 & 50 & 25 & 31 & 93 & 49 \\ 1960 & 68 & 37 & 44 & 129 & 59 \\ 1965 & 85 & 58 & 65 & 187 & 77 \\ 1970 & 100 & 100 & 100 & 312 & 100 \\ & & & & & \\ 1975 & 106 & 143 & 127 & 875 & 121 \\ 1977 & 118 & 169 & 148 & 1125 & 135 \\ 1979 & 132 & 188 & 163 & 1635 & 145 \\ 1980 & 141 & 199 & 163 & 1989 & 147 \\ 1981 & 147 & 207 & 164 & 1963 & 149 \\ 1982 & 144 & 204 & 160 & 1844 & 148 \\ 1983 & 146 & 214 & 165 & 1808 & 150 \\ 1984 & 152 & 239 & 179 & 1907 & 157 \\ 1985 & 150 & 252 & 185 & 1922 & 163\end{array}$

Source: GATT, International Trade 85-86 Table A1.

Note: Exports cover merchandise exports only 
Table 2. Elasticity of Trade Volume with Fespect to GNF Growth Manufactures

$\begin{array}{lll}1950 \text { to } 1955 & 1.21 & 1.14 \\ 1955 \text { to } 1960 & 1.23 & 1.18 \\ 1960 \text { to } 1965 & 1.20 & 1.14 \\ 1965 \text { to } 1970 & 1.32 & 1.19 \\ 1970 \text { to } 1975 & 1.18 & 1.04 \\ 1975 \text { to } 1980 & 1.14 & 1.06 \\ 1980 \text { to } 1995 & 1.12 & 1.03\end{array}$

Sources: Derived from Table 1. 


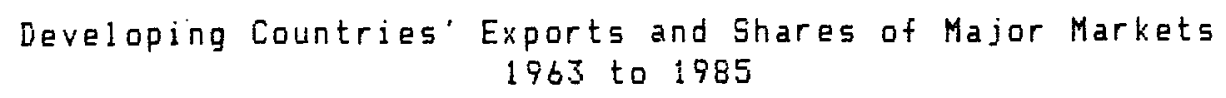

Exports of Manufactures Countries Mfd. Imports (billians of dollars) (percent)

$\begin{array}{ll}1953 & 2 \\ 1973 & 16 \\ 1979 & 53 \\ 1980 & 63 \\ & \\ 1981 & 67 \\ 1982 & 67 \\ 1983 & 77 \\ 1984 & 96 \\ 1985 & 97\end{array}$

\section{9}

6.6

8.5

8.9

106

116

114

124

147

149
9.9

10.2

11.3

12.6

11.9
To Developed World Share of DC

Total Exports To Developed World Share of
Countries
(billions of dollars) (percent)

23
83
299
396
373
318
295
314
295

32 110 414 555

20.6 19.2 25.3 27.9

Source: GATT International Trade 85/86. Table A3.

$545 \quad 27.7$

$480 \quad 26.0$

$447 \quad 24.7$

$465 \quad 24.4$

$440 \quad 22.9$ 